\title{
Blood Pressure Regulates Platelet-derived Growth Factor A-chain Gene Expression in Vascular Smooth Muscle Cells In Vivo An Autocrine Mechanism Promoting Hypertensive Vascular Hypertrophy
}

Nobuo Negoro, Yoshiharu Kanayama, Masashi Haraguchi, Naohiro Umetani, Masayo Nishimura, Yoshio Konishi, Junko Iwai, Mikio Okamura, Takatoshi Inoue, and Tadanao Takeda

First Department of Internal Medicine, Osaka City University Medical School, Osaka, 545, Japan

\begin{abstract}
To clarify the role of PDGF A-chain in hypertensive vascular hypertrophy of spontaneously hypertensive rats (SHRs), we studied levels of PDGF A-chain gene expression and transcription factors related to the gene in vascular smooth muscle cells (VSMCs) of SHRs in vivo. RNase protection assay and in situ hybridization showed that PDGF A-chain mRNA levels in VSMCs of SHRs were twofold higher than in those of normotensive Wistar-Kyoto rats. Gel retardation assays showed that levels of Sp1 and AP-2 in VSMCs of SHRs were twofold more abundant than in those of WistarKyoto rats. Treatment with four pharmacologically different species of antihypertensive drugs for 2 wk decreased the levels of both PDGF A-chain mRNA and Sp1, but not AP2 level in VSMCs of SHRs with regression of aortic hypertrophy, indicating that increases in levels of both PDGF Achain mRNA and Sp1 in VSMCs of SHRs were associated with high blood pressure. These results suggest that high blood pressure is a stimulus which upregulates PDGF Achain gene expression in VSMCs of SHRs, resulting in an autocrine enhancement in hypertensive vascular hypertrophy, and that the activation of the gene may be mediated through increases in Sp1 in these cells. (J. Clin. Invest. 1995. 95:1140-1150.) Key words: hypertension - vascular hypertrophy • PDGF A-chain • transcription factors • antihypertensive drugs
\end{abstract}

\section{Introduction}

Hypertensive vascular hypertrophy is a major pathological change in blood vessels after chronic exposure to high blood

Address correspondence to Nobuo Negoro, First Department of Internal Medicine, Osaka City University Medical School, 1-5-7 Asahi-machi, Abeno-ku, Osaka 545 Japan. Phone: 6-645-2106; FAX: 6-645-2107

Received for publication 27 June 1994 and in revised form 7 November 1994.

1. Abbreviations used in this paper: AII angiotensin II; Egr-1, early growth response; G6PD, glucose-6-phosphate dehydrogenase; GC factor, guanosine cytidine-rich sequence binding factor; PDGF-AA, dimer of PDGF A-chain; RT-PCR, reverse transcription-PCR; SD, SpragueDawley; SHR, spontaneously hypertensive rat; SRF, serum response factor; SSRF, shear stress response factor; TBP, TATA box binding protein; VSMC, vascular smooth muscle cell; WKY, Wistar-Kyoto.

J. Clin. Invest.

(C) The American Society for Clinical Investigation, Inc. $0021-9738 / 95 / 03 / 1140 / 11 \quad \$ 2.00$

Volume 95, March 1995, 1140-1150 pressure, and is characterized by the hypertrophy of vascular smooth muscle cells (VSMCs) ${ }^{1}(1-3)$. Vascular hypertrophy stimulates arteriosclerosis of vessel walls, resulting in acceleration of hypertension due to elevation of arterial resistance and also in progress of atherosclerosis in systemic vessels.

The molecular mechanism by which high blood pressure causes hypertensive vascular hypertrophy in VSMCs has not yet been determined. Although antihypertensive treatments can reduce hypertensive vascular hypertrophy, up to $6 \mathrm{yr}$ of antihypertensive treatment may be necessary to achieve normal vascular structure in patients with essential hypertension (4). Therefore, understanding the mechanisms of hypertensive vascular hypertrophy may allow the development of novel therapeutic approaches for the prevention of hypertensive vascular injury and the progress of atherosclerosis in hypertensive patients.

It has been suggested that numerous cellular growth regulatory molecules, in particular PDGF, are responsible for the migration, proliferation, and formation of connective tissue by VSMCs in vitro $(5,6)$. Recent studies $(7-10)$ showed that antisense PDGF A-chain oligonucleotides and antibodies to PDGF A-chain inhibited growth of cultured VSMCs by potent growth factors, IL-1, IL-6, angiotensin II (A II), and TGF$\beta$, indicating that the proliferation-inducing activities of these factors are mediated by autocrine secretion of a dimer of PDGF A-chain (PDGF-AA) in cultured VSMCs. Thus, PDGF-AA may be an important peptide for proliferation of VSMCs and a candidate growth regulatory molecule for the hypertrophy of VSMCs in hypertension.

PDGF is an $28-35 \mathrm{kD}$ peptide which is present in platelets and is secreted from VSMCs, endothelial cells, macrophages, and fibroblasts $(5,11)$. PDGF is composed of two closely related but nonidentical protein subunits, PDGF A-chain and Bchain, which form three possible dimeric configurations; $A A$, $\mathrm{BB}$, and $\mathrm{AB}$. All three forms of PDGF are mitogenic by binding to specific high-affinity cell surface receptors on mesenchymal cells such as VSMCs, fibroblasts, astrocytes, and osteoblasts (5). PDGF receptors consist of combinations of two different subunits, $\alpha$ - and $\beta$-receptors, which dimerize to form three distinct receptors; $\alpha \alpha, \alpha \beta$, and $\beta \beta$. According to the ligand specificity of the receptors, PDGF-AA binds $\alpha \alpha$ receptor, PDGF$\mathrm{AB}, \alpha \alpha$, or $\alpha \beta$ receptor, and PDGF-BB, $\alpha \beta$, or $\beta \beta$ receptor (12). The relative biological activity (mitogenicity and chemotactic activity) depends upon both the isoform of PDGF dimer and the relative number of $\alpha$ - and $\beta$-receptor subunits on the cell surface $(12,13)$. In vivo, normal VSMCs constitutively express small amounts of PDGF A-chain mRNA, produce homodimeric PDGF-AA, and evidently express PDGF $\alpha$ - and $\beta$ receptors $(12,14)$, while they rarely express PDGF $B$-chain mRNA or PDGF B-chain peptide, and PDGF B-chain mRNA is only detected in atherosclerotic lesions $(15,16)$.

Spontaneously hypertensive rats (SHRs) are a useful ge- 
netic animal model of human essential hypertension, in which systolic pressure at $10 \mathrm{wk}$ is elevated up to $160 \mathrm{mmHg}$, and aortas of SHRs show typical hypertensive vascular hypertrophy after 12 wk of age (17).

Recent studies $(18,19)$ have shown that the frequency of initiation of mRNA synthesis depends on nuclear transcription factors binding to cis elements in gene promoters. If PDGF Achain gene expression is modulated in hypertrophic VSMCs of SHRs, some transcription factors may be involved in the transcriptional changes of the gene in these cells.

In the present study, to examine the role of PDGF A-chain in hypertensive vascular hypertrophy of SHRs, we studied PDGF A-chain gene expression and transcription factors related to the gene in hypertrophic VSMCs of these animals in vivo. We found that an increase in PDGF A-chain gene expression in VSMCs of SHRs was associated with the hypertensive vascular hypertrophy, and that transcription factor Spl may mediate the increase of PDGF A-chain gene expression in hypertrophic VSMCs in the hypertensive rats.

\section{Methods}

Animals. Male 12-wk-old SHRs were obtained from Charles River Japan, Inc., Yokohama, Japan. Age-matched male 12-wk-old Wistar-Kyoto (WKY) and Sprague-Dawley (SD) rats were also purchased and used as normotensive controls. Animals were fed a normal sodium diet containing $0.3 \%$ sodium, and tap water ad lib. Pharmacologically different species of antihypertensive drugs were administered orally or through a catheter into the esophagus every day for $2 \mathrm{wk}$. The doses of antihypertensive drugs were as follows: angiotensin-converting enzyme inhibitor (enalapril), $25 \mathrm{mg} / \mathrm{kg}$ per d; $\alpha$-blocker (doxazosin), $1 \mathrm{mg}$ / $\mathrm{kg}$ per $\mathrm{d}$; Ca-antagonist (nicardipine), $15 \mathrm{mg} / \mathrm{kg}$ per $\mathrm{d}$; and smooth muscle relaxant (hydralazine), $10 \mathrm{mg} / \mathrm{kg}$ per $\mathrm{d}$. Blood pressure was measured by the tail-cuff method.

Tissue preparation. Animals were anesthetized with pentobarbital and killed by exsanguination through the abdominal aorta. VSMCs of the thoracic aorta medial layer were carefully separated from the endothelium and adventitia by stainless steel oculist's forceps under a dissecting microscope. Care was taken not to include adventitial tissue in samples. This technique is identical to that used for the isolation of cultured VSMCs. No contamination of endothelium or adventitia was found in any samples by light microscopic examination of hematoxylin eosin-stained specimens or by Northern blot analysis for angiotensinconverting enzyme and PDGF B-chain/c-sis mRNAs, both of which are absent from VSMCs (15). Hypertrophy index was calculated by the ratio of weight of total thoracic aorta to body weight in each rat.

Purification of RNA. Aortic medial layers were immediately lysed in guanidium solution containing $4 \mathrm{M}$ guanidine isothiocyanate, $50 \mathrm{mM}$ potassium acetate $(\mathrm{pH} 5.1), 0.5 \%$ sodium lauryl sarcosinate, and $1 \%$ ( vol/vol) 2-mercaptoethanol, and homogenized in a Polytron (Brinkmann Instruments Inc., Westbury, NY) at high speed for $15 \mathrm{~s}$. Total cellular RNA was isolated from the lysate by a step gradient ultracentrifugation with cesium trifluoro acetic acid (Pharmacia LKB Biotechnology Inc., Uppsala, Sweden). RNA concentration was determined by $\mathrm{OD}$ at $260 \mathrm{~nm}$. Ratios of $\mathrm{OD}_{260 \mathrm{~nm}}$ to $\mathrm{OD}_{280 \mathrm{~nm}}$ of the samples were $\sim 2.0$.

Cloning and identification of PDGF A-chain and glucose-6-phosphate dehydrogenase (G6PD) cDNAs. Cloning of PDGF A-chain and G6PD cDNAs was performed by insertion of PCR products into cloning expression vectors $(20,21)$. Oligonucleotide primers were synthesized with an automatic DNA synthesizer (Applied BioSystems, Inc., Tokyo, Japan). Primers were identical to the 5 '-end ( 5 '-AAGCATGTGCCGGAGAAGCG-3') and complementary to the $3^{\prime}$-end (5'-GTCCAGGTGAGGTTAGAGGA-3') of the coding region of rat PDGF A-chain cDNA (22), and identical to the 5'-end (5'-GAGGACCAGATCTACCGCAT-3') and complementary to the $3^{\prime}$ '-end (5'-GTCCGTGATGAGAAGGTCAA-3') of the coding region of rat G6PD cDNA (23).
First strand cDNA was synthesized from total RNA with Moloney murine leukemia virus reverse transcriptase (Bethesda Research Laboratories, Gaithersburg, MD), heat-denatured at $95^{\circ} \mathrm{C}$ for $5 \mathrm{~min}$ and diluted to $100 \mu \mathrm{l}$ with distilled water. $10 \mu \mathrm{l}$ of the diluted cDNA product was mixed with $10 \mu \mathrm{l}$ of $10 \times$ PCR buffer $(0.1 \mathrm{M}$ Tris- $\mathrm{HCl}$ [pH 8.3 at $23^{\circ} \mathrm{C}$ ], $0.5 \mathrm{M} \mathrm{KCl}, 25 \mathrm{mM} \mathrm{MgCl}$, and $0.1 \%$ [wt/vol] gelatin), $8 \mu \mathrm{l}$ of $1.25 \mathrm{mM}$ each dNTP, $5 \mu \mathrm{l}$ of $10 \mathrm{mM}$ upstream sense primer, $5 \mu \mathrm{l}$ of $10 \mathrm{mM}$ downstream antisense primer, and $2.5 \mathrm{U}$ of Taq DNA polymerase (Perkin-Elmer Cetus Instruments, Norwalk, CT), and the volume was adjusted to $100 \mu \mathrm{l}$ with distilled water. PCR was performed for 30 cycles in an automatic thermocontroller with a thermal cycle profile for amplification of target sequences of $(a)$ denaturing for $1 \mathrm{~min}$ at $94^{\circ} \mathrm{C},(b)$ primer annealing for $2 \mathrm{~min}$ at $58^{\circ} \mathrm{C}$, and $(c)$ primer extension for $2 \mathrm{~min}$ at $72^{\circ} \mathrm{C}$. PCR products were cloned into PCR II cloning vector (Invitrogen, La Jolla, CA) according to the manufacturer's instructions. Insert-positive plasmids were sequenced by the dideoxynucleotide chain-termination method using Bca DNA polymerase (Takara Shuzo Co., Kyoto, Japan) (24). After sequencing to determine the orientation of the fragment within the plasmids, the DNA was linearized by digestion with HindIII or XhoI to make templates for riboprobes.

RNase protection assays. The antisense riboprobe for PDGF Achain mRNA used in the present study was capable of detecting all three forms of alternatively spliced transcripts of the PDGF A-chain gene (25). The riboprobe was synthesized by incubation of $0.5 \mu \mathrm{g}$ $(\sim 0.2 \mathrm{pM})$ linearized plasmid template DNA of PDGF A-chain in a total volume of $10 \mu \mathrm{l}$ containing $1 \times$ transcription buffer (Takara Shuzo Co.), $10 \mathrm{mM}$ DTT, $10 \mathrm{U}$ of placental RNase inhibitor (Pharmacia LKB Biotechnology Inc.), $1 \mathrm{ng}$ of BSA, $0.5 \mathrm{mM}$ each of ATP, GTP, and CTP at a concentration of $50 \mu \mathrm{Ci}\left[\alpha{ }^{32} \mathrm{P}\right] \mathrm{UTP}(\sim 800 \mathrm{Ci} / \mathrm{mM}$; Amersham Japan, Inc., Tokyo, Japan), $10 \mathrm{U}$ of T7 RNA polymerase, and RNase-free water (26). After incubation for $60 \mathrm{~min}$ at $37^{\circ} \mathrm{C}, 0.5 \mathrm{nM}$ each of ATP, GTP, CTP, and UTP and $5 \mathrm{U}$ of T7 RNA polymerase were added to the mixture for elongation of the radiolabeled riboprobe to the full length. After incubation for $60 \mathrm{~min}$ at $37^{\circ} \mathrm{C}, 1 \mu \mathrm{g}$ RNasefree DNase (Takara Shuzo Co.) was added to the mixture and incubated for $15 \mathrm{~min}$ at $37^{\circ} \mathrm{C}$. The samples were electrophoresed through $4 \%$ polyacrylamide/8 M urea gels which were then exposed to XAR x-ray film. The gel fragment at the positive signal was excised and the riboprobe was eluted by overnight incubation at $37^{\circ} \mathrm{C}$ in $0.5 \mathrm{M}$ sodium acetate (pH 5.0) and $1 \mathrm{mM}$ EDTA (27). Riboprobes were labeled to a specific activity of $\sim 2.5 \times 10^{8} \mathrm{cpm} / \mu \mathrm{g}$.

RNase protection assays were performed according to the manufacturer's instructions (RPA II; Ambion, Inc., Austin, TX). Pooled samples of total RNA (3 $\mu \mathrm{g}$ ) from VSMCs in each group were hybridized overnight with molar excesses of PDGF A-chain riboprobe $\left(10^{5} \mathrm{cpm}\right.$ $=\sim 400 \mathrm{pg}$ ). Single-stranded RNA was removed by digestion with RNase A/RNase T1 for $30 \mathrm{~min}$ at $37^{\circ} \mathrm{C}$ followed by incubation for 15 min at $37^{\circ} \mathrm{C}$ with proteinase $\mathrm{K}$ and $10 \%$ SDS. The protected fragments were phenol-chloroform extracted, ethanol precipitated, and analyzed on $4 \%$ polyacrylamide/ $8 \mathrm{M}$ urea gels, which were then dried and exposed to XAR x-ray film with an intensifying screen for 3-5 d.

Equal amounts of RNA were applied to each gel, as confirmed by RNase protection assay using a riboprobe for G6PD mRNA, a housekeeping gene transcript assumed to be similarly abundant in VSMCs and not to change in experiments. The G6PD antisense riboprobe was synthesized from the linearized plasmid template by the same method used for the PDGF A-chain riboprobe with the exception of incubation with SP6 RNA polymerase at $40^{\circ} \mathrm{C}$ instead of incubation with T7 RNA polymerase at $37^{\circ} \mathrm{C}$. RNA samples $(3 \mu \mathrm{g})$ from VSMCs were hybridized overnight with molar excesses of riboprobe G6PD receptor $\left(2 \times 10^{5} \mathrm{cpm}=\sim 800 \mathrm{pg}\right)$ and RNase protection assays were performed as described above.

The rat PDGF A-chain riboprobe used in the present study consisted of 431 nucleotides corresponding to 304 nucleotides of the PDGF Achain coding region and 127 nucleotides of vector sequences. The G6PD riboprobe used in these studies consisted of 412 nucleotides corresponding to 293 nucleotides of the G6PD coding region and 119 nucleotides of vector sequences. For comparison of amounts of PDGF A-chain 

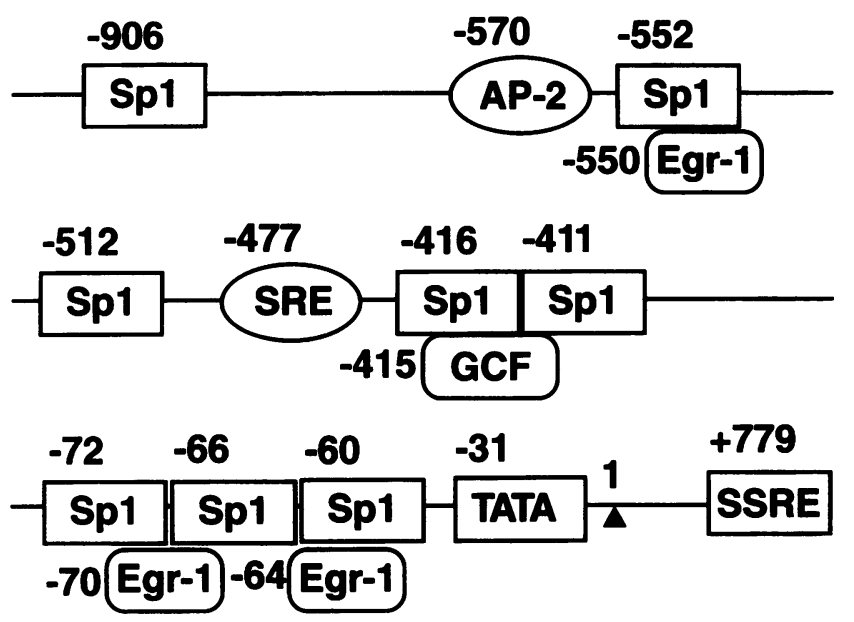

Figure 1. Known transcription factor binding sites in the promoter region of the human PDGF A-chain gene. In the promoter region of the gene, there are a TATA box, eight Sp1 sites, two Egr-1 sites, an AP-2 site, a GC factor $(G C F)$ site, a serum response element $(S R E)$ and a shear stress responsive element (SSRE). Numbers at the top indicate relative position in base pairs from the initiation site of transcription.

mRNA in VSMCs, scanning densitometry was used to give quantitative data.

In situ hybridization. In situ hybridization was performed by a slight modification of the method described previously (28). Briefly, tissues were immediately immersion fixed in phosphate buffer containing $4 \%$ paraformaldehyde for $2 \mathrm{~h}$, cryoprotected, and cut into 6- $\mu \mathrm{m}$ frozen sections which were thaw mounted onto poly-L-lysine subbed slides. After treatment with proteinase $\mathrm{K}$ and acetylation of amino groups by acetic anhydride, sections were prehybridized in $2 \times$ SSC buffer containing $50 \%$ deionized formamide, $100 \mu \mathrm{g} / \mathrm{ml}$ denatured salmon sperm DNA, $10 \times$ Denhardt's solution $(0.2 \%$ Ficoll $400,0.2 \%$ polyvinylpyrrolidone, and $0.2 \% \mathrm{BSA}$ ), $0.1 \%$ SDS, and $10 \mathrm{mM}$ DTT, and hybridized in fresh identical solution containing the ${ }^{35} \mathrm{~S}$-labeled PDGF A-chain antisense RNA probe at $42^{\circ} \mathrm{C}$ overnight. After DNase-free RNase treatment $(25 \mu \mathrm{g} / \mathrm{ml})$ for $30 \mathrm{~min}$ at $37^{\circ} \mathrm{C}$ and washings up to $0.1 \times \mathrm{SSC}$ at $42^{\circ} \mathrm{C}$, slides were dipped in photographic emulsion (Fuji Film Inc., Tokyo, Japan) and exposed for $3 \mathrm{~d}$ at $4^{\circ} \mathrm{C}$. Sections were developed, counterstained with hematoxylin, and observed by light microscopy. Control slides were incubated with sense riboprobe of a similar specific activity. ${ }^{35}$ S-labeled PDGF A-chain antisense RNA and sense RNA were synthesized by incubation of the linearized plasmid templates with [ $\alpha$ ${ }^{35}$ S ] UTP. These riboprobes were labeled to a sp act of $\sim 0.3 \times 10^{8}$ $\mathrm{dpm} / \mu \mathrm{g}$.

Reverse-transcription polymerase chain reaction $(R T-P C R)$ assay. The amounts of RNA in the aortic medial layer of individual animals were too low $(\sim 1.5 \mu \mathrm{g})$ to allow detection of PDGF A-chain mRNA by RNase protection assay. To overcome this problem, we established a quantitative RT-PCR assay for the detection of PDGF A-chain mRNA in individual aortic medial layers as previously described (21).

The same primers and the same thermal cycle profile of PCR were used as described above. To confirm the specificity of the method and to reduce the number of PCR cycles, the PCR products were detected by Southern blot hybridization with radiolabeled oligonucleotide probes specific for each cDNA. Briefly, aliquots ( $250 \mathrm{ng} / 20 \mu \mathrm{l}$ ) of RNA were reverse-transcribed to single-stranded cDNA and amplified by PCR. To improve the accuracy of the amplification of mRNA (21), these procedures were performed at the same time and under the same conditions. Aliquots $(5 \mu \mathrm{l})$ of PCR products were dot blotted onto nylon membranes (Hybond-N Plus; Amersham Japan, Inc.), and fixed by ultraviolet irradiation $\left(120 \mathrm{~mJ} / \mathrm{cm}^{2}\right)$. The blotted membranes were prehybridized in a solution containing $2 \times$ sodium chloride sodium phos-
Table I. Oligonucleotide Sequences Used in the Gel Retardation Assay

\begin{tabular}{ll}
\hline Transcription factor & \multicolumn{1}{c}{ Sense oligonucleotide sequence } \\
\hline Sp1 & GCCCCAAACCCGCCCCCCTCCTTC \\
AP-2 & TTCAGATGCCCAGGCCTCGGATC \\
Egr- ${ }^{*}$ & CGGATCCTGCGGGGGCGCGTGGCAG \\
TBP & CGGCGGCGGCTATAACCCTCTCCCC \\
SRF & TCCCCTCCTTTATGGAGAGAGG \\
GC factor & CGGAGCGCGCGGGGCGACGGCTCT \\
SSRF & GCTCCAGCCGGTCTCCTGTGGCGG \\
\hline
\end{tabular}

Oligonucleotide sequences are designed from the promoter region of human PDGF A-chain gene. Underlined sequences indicate consensus sequences specific for each transcription factor. * Oligonucleotide sequence for Egr-1 was deleted from the original Sp1 consensus sequence in the human PDGF A-chain gene.

phate $(1 \times$ sodium chloride sodium phosphate is $0.15 \mathrm{M} \mathrm{NaCl}, 10 \mathrm{mM}$ $\mathrm{Na}_{2} \mathrm{HPO}_{4}$ and $1 \mathrm{mM}$ EDTA), $5 \times$ Denhardt's solution, $0.5 \%$ SDS, and $20 \mu \mathrm{g} / \mathrm{ml}$ denatured salmon sperm DNA. Southern hybridization was performed at $52^{\circ} \mathrm{C}$ for $24 \mathrm{~h}$ using the same buffer containing ${ }^{32} \mathrm{P}$-labeled oligonucleotide probe ( $5^{\prime}$-ATGACCGTCCTGGTCTTGCA-3'). Probes were radiolabeled to a sp act of $7 \times 10^{6} \mathrm{dpm} / \mathrm{pM}$ by the $5^{\prime}$ end labeling method with $\left[\gamma^{32} \mathrm{P}\right]$ ATP $(\sim 3,000 \mathrm{Ci} / \mathrm{mM})$ and T4 polynucleotide kinase (26). Hybridized membranes were washed twice for $30 \mathrm{~min}$ at a stringency of $1 \times$ sodium chloride sodium phosphate with $0.1 \%$ SDS at the calculated melting temperature $-10^{\circ} \mathrm{C}(26)$. Autoradiography was performed for $3 \mathrm{~h}$ at room temperature with an intensifying screen, and scanning densitometry was used to give quantitative data. Assays were performed in duplicate. A no-cDNA control was always used as a negative control and G6PD mRNA in the samples was used as an internal control to confirm that mRNA in each sample was equally amplified. The sequence for the oligonucleotide probe specific for amplified G6PD cDNA was 5'-ATCCTGTTGGCAAATCTCAGCAC-3'. Gene expression was expressed as the ratio of signal intensities for PDGF A-chain to G6PD on autoradiograms.

Oligonucleotide probes for gel retardation assays. Since a recent report (29) indicated that both nucleotide sequence and structure of the promoter region of PDGF A-chain gene are highly conserved in human and mouse, we expected the promoter region of the rat PDGF A-chain gene to also be highly conserved. Seven transcription factors were selected from the DNA consensus motifs in the promoter region of the human PDGF A-chain gene (Fig. 1) $(30,31)$. In the 5'-flanking region of the gene, there are a TATA box, eight Spl sites, two early growth response-1 (Egr-1) sites, an AP-2 site, guanosine cytidine-rich sequence binding factor ( $\mathrm{GC}$ factor) site, a serum response element, and a shear stress responsive element (32-38). According to recent reports, proteins including TFIID complexes binding to the TATA box are referred to as TATA box binding proteins (TBP), proteins binding to the serum response element; serum responsive factor (SRF), and proteins binding to the shear stress responsive element; shear stress response factor (SSRF).

The sequences of oligonucleotides used in the present study are depicted in Table I. The Sp1 site in the Egr-1 consensus sequence was deleted to exclude false binding of Sp1 to the Egr-1 probe. Each sense oligonucleotide was radiolabeled to a sp act of $7 \times 10^{6} \mathrm{dpm} / \mathrm{pM}$ by $5^{\prime}$ end-labeling method as described above. Aliquots of sense and antisense oligonucleotides were boiled for $3 \mathrm{~min}$ in a solution containing $10 \mathrm{mM}$ Tris- $\mathrm{HCl}$ ( $\mathrm{pH} \mathrm{7.6),} 50 \mathrm{mM} \mathrm{NaCl}$, and $1 \mathrm{mM}$ EDTA for $3 \mathrm{~min}$ and slowly cooled to room temperature to allow annealing.

Gel retardation assays. Cellular extracts from aortic medial layers were used in the gel retardation assays, because aortic medial layers were too stiff and small to obtain enough numbers of nuclei for assays 
Table II. Blood Pressure, Heart Rate, and Hypertrophy Index of Rats

\begin{tabular}{|c|c|c|c|c|c|c|}
\hline Group & & Blood pressure & Heart rate & Weight of thoracic aorta & Body weight & Hypertrophy index* \\
\hline & $n$ & $m m H g$ & per min & $m g$ & $g$ & $\times 10^{3}$ \\
\hline SHR & 6 & $190 \pm 2$ & $367 \pm 8$ & $99 \pm 3$ & $330 \pm 4$ & $0.30 \pm 0.01$ \\
\hline SHR + enalapril & 5 & $132 \pm 4^{\ddagger}$ & $366 \pm 8$ & $78 \pm 4^{\ddagger}$ & $326 \pm 6$ & $0.24 \pm 0.01^{\ddagger}$ \\
\hline SHR + doxazosin & 6 & $151 \pm 3^{\ddagger}$ & $375 \pm 9$ & $81 \pm 4^{\ddagger}$ & $324 \pm 5$ & $0.25 \pm 0.02^{\ddagger}$ \\
\hline SHR + nicardipine & 5 & $154 \pm 2^{\ddagger}$ & $402 \pm 10^{\ddagger}$ & $78 \pm 3^{\ddagger}$ & $321 \pm 6$ & $0.24 \pm 0.01^{\ddagger}$ \\
\hline SHR + hydralazine & 5 & $149 \pm 5^{\ddagger}$ & $410 \pm 14^{\ddagger}$ & $82 \pm 1^{\ddagger}$ & $322 \pm 5$ & $0.26 \pm 0.01^{\ddagger}$ \\
\hline WKY & 5 & $122 \pm 3^{\ddagger}$ & $351 \pm 11$ & $81 \pm 3^{\ddagger}$ & $338 \pm 6$ & $0.24 \pm 0.01^{\ddagger}$ \\
\hline SD & 5 & $127 \pm 2^{\ddagger}$ & $361 \pm 4$ & $85 \pm 1^{\ddagger}$ & $341 \pm 4$ & $0.25 \pm 0.01^{\ddagger}$ \\
\hline
\end{tabular}

Results are expressed as the mean \pm SE. SHR + , SHR treated with the indicated antihypertensive drugs for 2 wk. All rats were 14 wk old. * Hypertrophy index was calculated by the ratio of weight of total thoracic aorta to body weight in each rat. ${ }^{\ddagger} \boldsymbol{P}<0.05$ vs SHRs by ANOVA followed by Duncan's multiple range test.

by the conventional method (39), which routinely give $\sim 15 \%$ of nuclear yields, as previously reported (40). Since cellular extracts from cultured VSMCs showed the same results on gel retardation assay as nuclear extracts from these cells, we substituted cellular extracts for nuclear extracts as samples. Transcription factors are present in the nucleus $(18,39)$ and there are wide variations in cellular protein content in VSMCs of SHRs with increases in number of polyploid VSMCs (17, 40). Therefore, we considered that to compare amounts of nuclear transcription factors in VSMCs of SHRs, it is better to adjust samples by nuclear numbers rather than by protein content.

Four thoracic aorta medial layers were rinsed in cold saline and homogenized at $4^{\circ} \mathrm{C}$ in $2 \mathrm{ml}$ of a extraction buffer containing $20 \mathrm{mM}$ Hepes-NaOH (pH 7.6), 20\% (vol/vol) glycerol, $0.35 \mathrm{M} \mathrm{NaCl}, 5 \mathrm{mM}$ $\mathrm{MgCl}_{2}, 0.1 \mathrm{mM}$ EDTA, $1 \mathrm{mM}$ DTT, $0.5 \mathrm{mM}$ PMSF, $1 \mu \mathrm{g} / \mathrm{ml}$ pepstatin A, $1.2 \mu \mathrm{g} / \mathrm{ml}$ spermidine, and $2 \mu \mathrm{g} / \mathrm{ml}$ aprotinin in a Polytron with a small cutting blade at high speed for $60 \mathrm{~s}$. The homogenate was vigorously shaken and rocked at $4^{\circ} \mathrm{C}$ for $30 \mathrm{~min}$ and insoluble materials including histones were precipitated by centrifugation at $40,000 \mathrm{~g}$ for $30 \mathrm{~min}$ at $4^{\circ} \mathrm{C}$. The supernatant was dialyzed against a binding buffer containing $20 \mathrm{mM}$ Hepes- $\mathrm{NaOH}$ (pH 7.6), 20\% (vol/vol) glycerol, 0.1 $\mathrm{M} \mathrm{NaCl}, 5 \mathrm{mM} \mathrm{MgCl}, 0.1 \mathrm{mM}$ EDTA, $1 \mathrm{mM}$ DTT, and $0.5 \mathrm{mM}$ PMSF. The dialysate was cleared by centrifugation at $10,000 \mathrm{~g}$ for 15 $\min$ at $4^{\circ} \mathrm{C}$ and frozen at $-80^{\circ} \mathrm{C}$ in aliquots until use.

Gel retardation assays were performed as previously described (39). Briefly, a constant DNA amount of histone-depleted cellular extract (50 ng of DNA, equivalent to $\sim 1.6 \times 10^{4}$ mammalian nuclei [25]) was incubated in $20 \mu \mathrm{l}$ of a reaction mixture containing $50 \mathrm{mM}$ Hepes- $\mathrm{KOH}$ (pH 7.6), 50 mM KCl, 1 mM DTT, 0.5 mM EDTA, 1\% glycerol, 0.5 $\mathrm{mM}$ PMSF, $1 \mu \mathrm{g}$ of nonspecific DNA (pBR322 plasmid), and $2 \mu \mathrm{g}$ of poly $(\mathrm{dl}-\mathrm{dC}) \cdot \operatorname{poly}(\mathrm{dl}-\mathrm{dC})$. In the assay for measurement of TBP, poly $(\mathrm{dG}-\mathrm{dC}) \cdot$ poly $(\mathrm{dG}-\mathrm{dC})$ were used instead of poly $(\mathrm{dl}-\mathrm{dC}) \cdot$ poly $(\mathrm{dl}-\mathrm{dC})$. The ${ }^{32} \mathrm{P}$-labeled DNA probe (30 fmol, $\sim 80,000 \mathrm{cpm}$ ) was added last to the reaction mixture and incubated for $30 \mathrm{~min}$ at $20^{\circ} \mathrm{C} .5$ $\mu \mathrm{l}$ of each sample was loaded into each well of a $4 \%$ polyacrylamide gel with $1 \times$ Tris/acetate/EDTA (6.7 mM Tris- $\mathrm{HCl}$ [pH 7.8], $3.3 \mathrm{mM}$ sodium acetate, $1 \mathrm{mM}$ EDTA) and electrophoresed at $4^{\circ} \mathrm{C}$ for $70 \mathrm{~min}$ at $120 \mathrm{~V}$. The gel was dried and the retarded bands consisting of proteinoligonucleotide complex were analyzed by autoradiography at $-80^{\circ} \mathrm{C}$ for 2-24 h. Scanning densitometry was used to obtain data for comparing relative amounts of transcription factors in samples. Specificity of the assays was evaluated by coincubation with each cold competitor oligonucleotide. All assays were performed in duplicate and results were obtained from the average of three independent experiments.

Statistics. Statistical comparisons were performed using the MannWhitney U-test, one-way ANOVA, and Duncan's multiple range test with statistical software programs (StatView and SuperANOVA; Abacus Concepts, Inc., Berkeley, CA). Correlation coefficients were calculated by Spearman's nonparametric rank correlation test (41) or Pear- son's product-moment correlation test under the consideration of suitability for each case. " $r s$ " means correlation coefficiency for Spearman's rank test and " $r$ " means correlation coefficiency for Pearson's test. All $P$ values are two-tailed and significance was set at $P$ $<0.05$. Results are reported as the mean \pm SE.

\section{Results}

Blood pressure, heart rate, and hypertrophy index. The systolic blood pressure of 14-wk-old SHRs was significantly higher than those of normotensive WKY and SD rats (both $P<0.01$; Table II). Treatment with antihypertensive drugs for 2 wk lowered blood pressure levels in SHRs $(P<0.01$, respectively). As expected, nicardipine and hydralazine treatment increased heart rate of SHRs, but other drug treatments did not. Increases in body weight of rats $(\sim 40 \mathrm{~g})$ were observed in all groups for 2 wk. The levels of hypertrophy index in control SHRs were higher than those in age-matched WKY and SD rats (both $P$ $<0.05)$ and in SHRs treated with antihypertensive drugs $(P<0.05)$.

In situ hybridization histochemistry of PDGF A-chain mRNA in aortic medial layers. Microscopic examination of hematoxylin eosin-stained cross-sections of thoracic aortas at 14 wk of age showed medial thickening of aortas in SHRs and that VSMCs of the medial layers were hypertrophied as reported previously (1).

In situ hybridization histochemistry showed positive silver grain deposition indicating PDGF A-chain mRNA in the aortic medial layers (Fig. 2), and a small number of grains were also observed in the adventitial cells. In contrast, a minimal amount of silver grains, consistent with nonspecific background staining, was observed in tissue incubated with the labeled sense probe, indicating that the positive signals were specific for PDGF A-chain mRNA. Amounts of silver grains per nucleus in aortic medial layer of SHRs were greater than in those of WKY rats $(P<0.05$ by Mann-Whitney U-test), indicating that the increased level of PDGF A-chain mRNA detected in the RNase protection assay was located in VSMCs.

Evaluation of RNase protection assays. RNase protection assay for PDGF A-chain mRNA in VSMCs of aortic medial layers showed a single protected fragment (Fig. 3), indicating that the specificity of the assay was sufficient to detect mRNA in the tissue. RNase protection assay for G6PD mRNA also showed a single protected band in total RNA from VSMCs. 
A

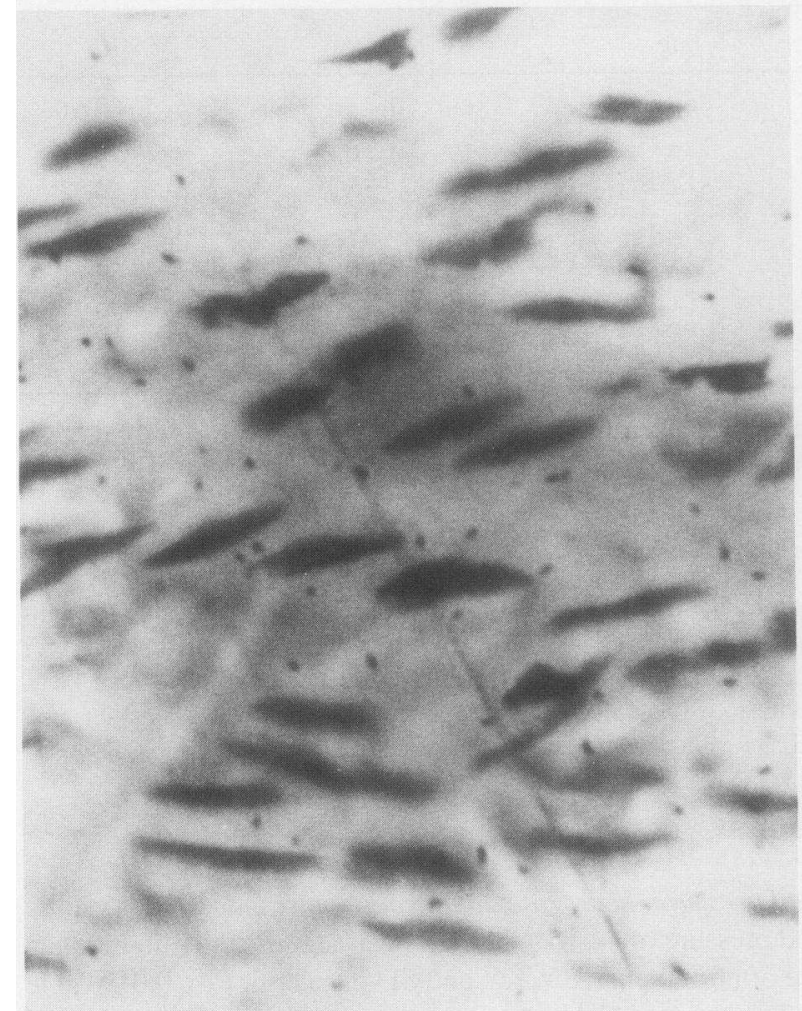

C

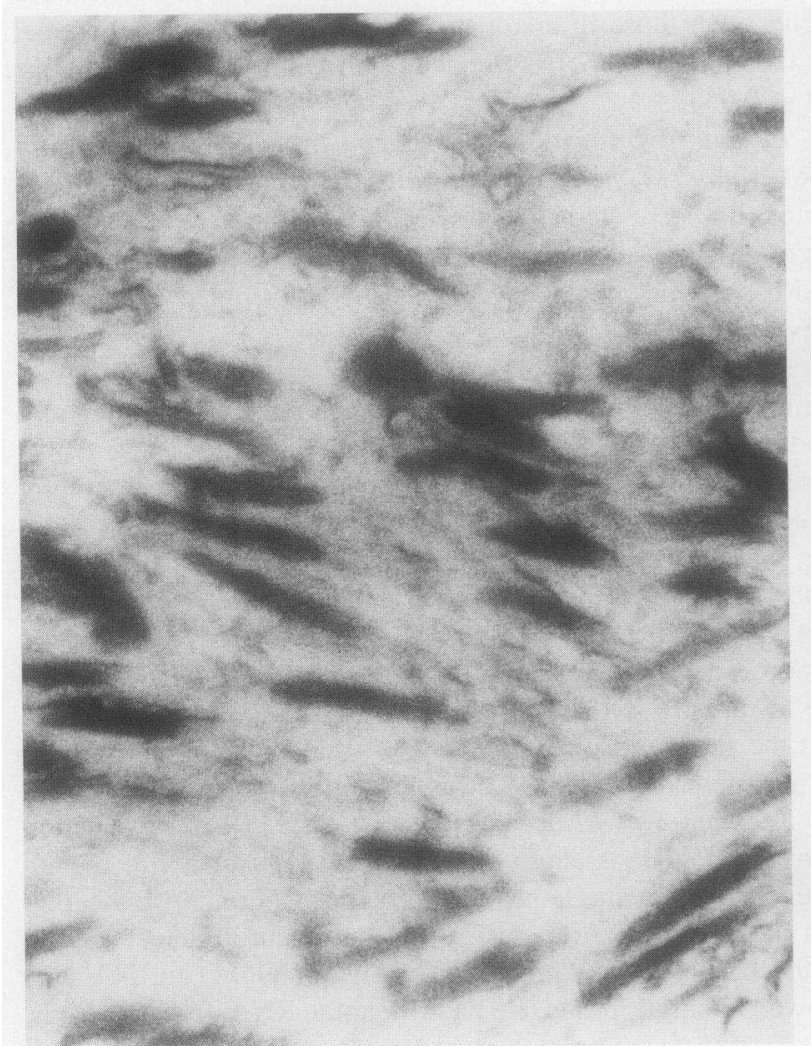

B

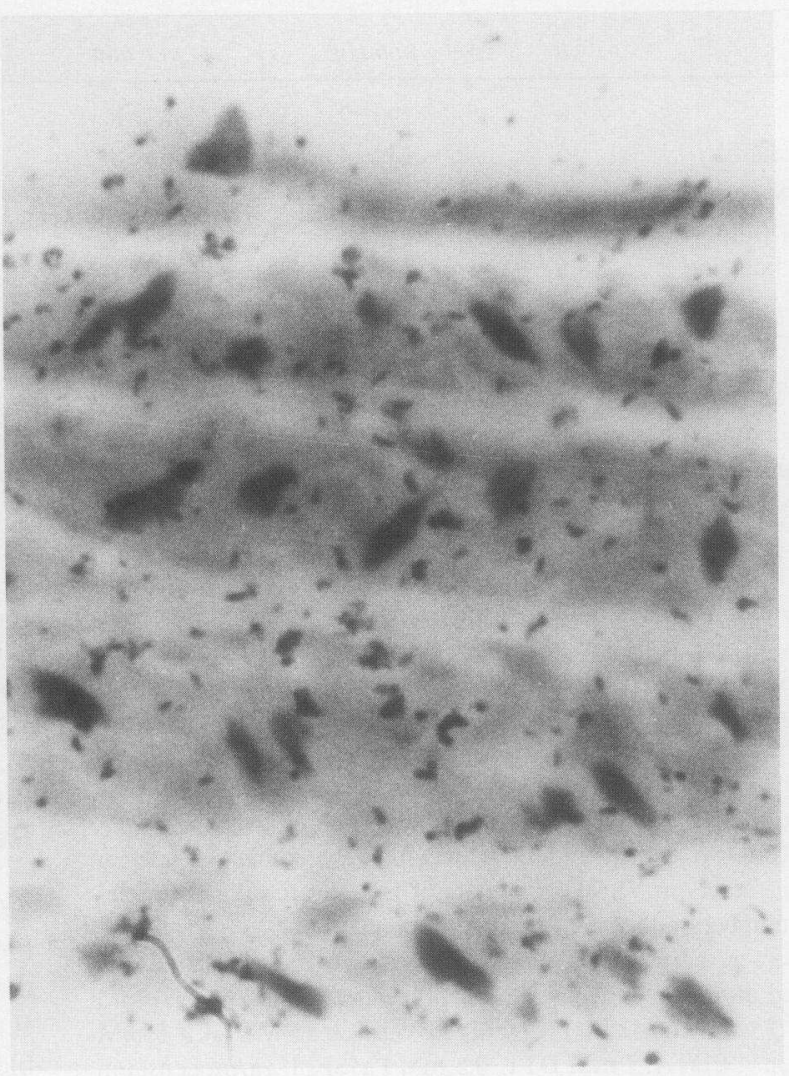

D

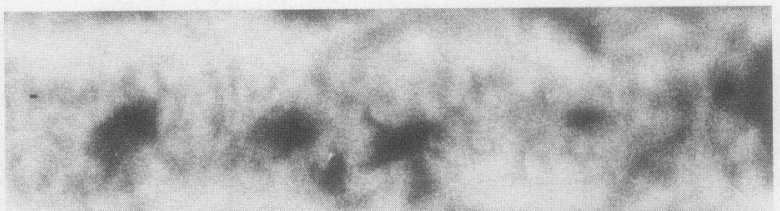

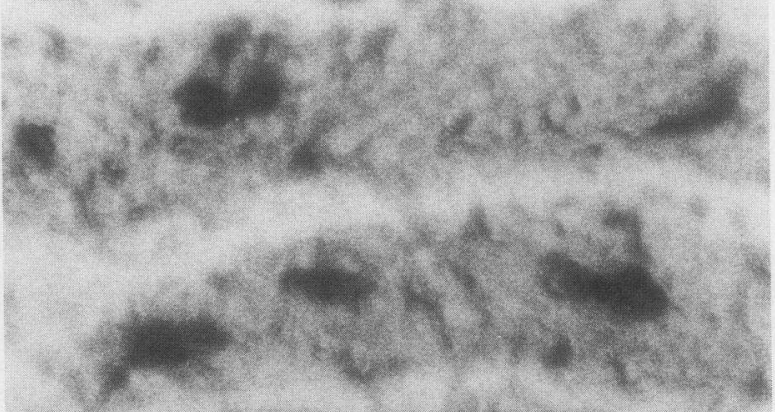

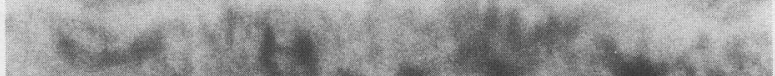

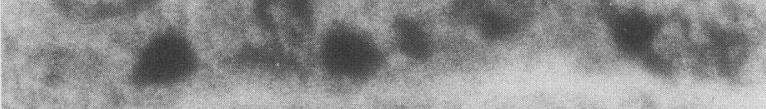

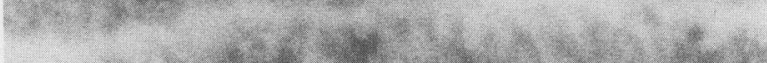
20

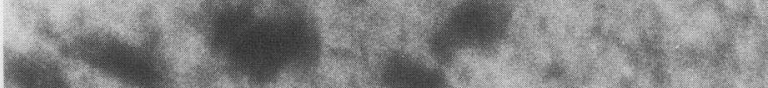

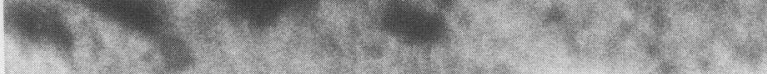

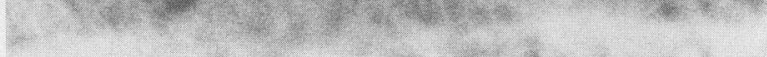

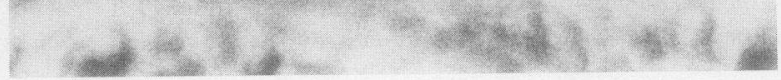



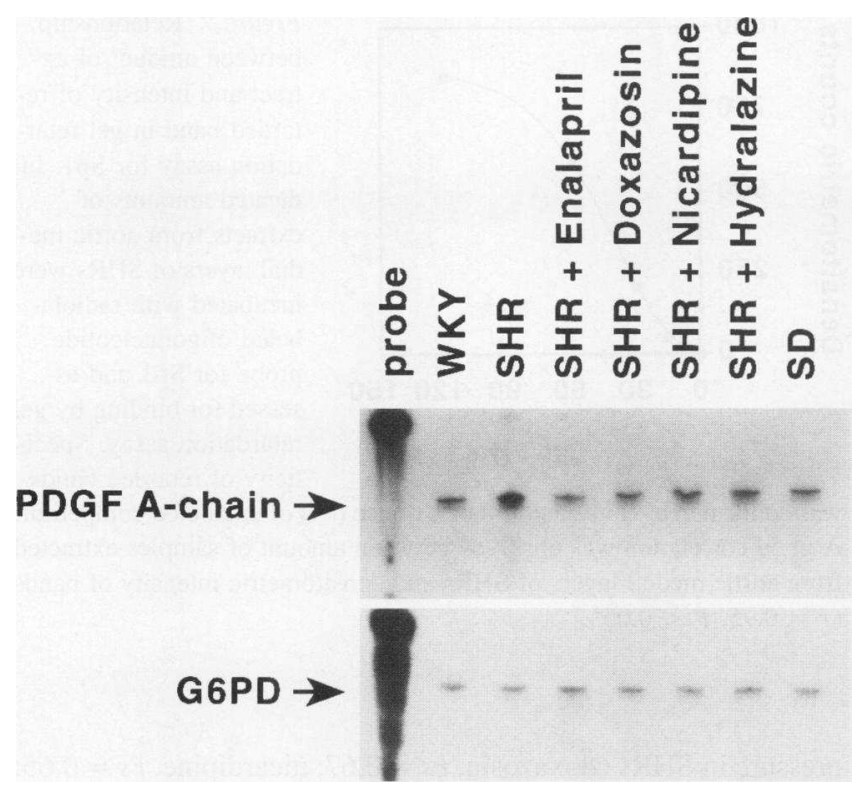

Figure 3. RNase protection analysis for PDGF A-chain mRNA in aortic smooth muscle cells. RNA samples were purified from medial layers of five thoracic aortas. Aliquots ( $3 \mu \mathrm{g})$ of RNA from aortic medial layers of WKY, SHR, SHR treated with antihypertensive drugs for 2 wk (SHR + indicated drugs) and SD rats were hybridized and protected with radiolabeled antisense riboprobes for PDGF A-chain mRNA or G6PD mRNA, yielding the 304- or 293-bp protected fragments, respectively. Lanes probe correspond to undigested riboprobes. The representative autoradiogram in three experiments was shown.

To examine the linearity between amount of RNA loaded and densitometric intensity of RNase-protected bands, the dose-dependency of PDGF A-chain mRNA in the assay was investigated. As shown in Fig. 4, there was a good correlation between the amount of RNA and intensity of protected band ( $r=0.99$, $P<0.05$ ), indicating that the assay was sufficiently sensitive and suitable for use in measurement of specific mRNA levels in small amounts of RNA. The intraassay variation of the assay was $12 \%(n=5)$.

PDGF A-chain gene expression in vascular smooth muscle cells and effects of antihypertensive treatments. The results of the RNase protection assay indicated that PDGF A-chain mRNA levels in VSMCs of SHRs $(231 \pm 21 \%, n=3)$ were approximately twofold higher than in those of WKY rats $(100 \pm 12 \%, n=3)$ and SD rats $(103 \pm 11 \%, n=3)(P<0.05$, SHRs vs WKY rats by Duncan's test; $P<0.05$, SHRs vs SD rats) (Fig. 3). On the other hand, there was little difference in amount of G6PD mRNA between VSMCs from SHR, WKY, and SD rats.

After treatment with antihypertensive drugs for $2 \mathrm{wk}$, PDGF A-chain mRNA levels in VSMCs of SHRs were decreased with both decreases in blood pressure and regression of vascular

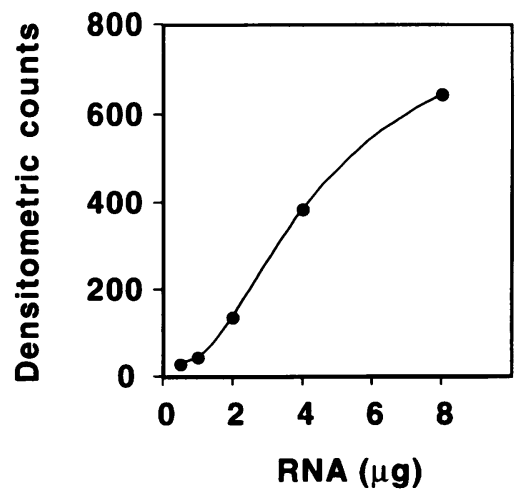

Figure 4. Relationship between amount of total RNA and intensity of RNase-protected bands in RNase protection assay for PDGF A-chain mRNA. Indicated amounts of total RNA from aortic medial layers of SHRs were hybridized and protected with antisense PDGF A-chain riboprobe, yielding the same 304-bp protected fragment. A good correlation was observed between amount of total RNA from vascular smooth muscle cells and densitometric intensity of RNase-protected bands ( $r$ $=0.99, P<0.05$ ).

hypertrophy in SHRs, while G6PD mRNA in these cells was almost unchanged. Decreases in PDGF A-chain mRNA levels in VSMCs of SHRs were commonly observed with treatments with all pharmacologically different species of antihypertensive drugs, indicating that these changes were not due to genomic background of the strains, but were a result of changes in blood pressure level in SHRs.

Evaluation of RT-PCR assays. Southern blot analysis of RT-PCR products for PDGF A-chain mRNA showed a single band of $304 \mathrm{bp}$ (data not shown), which agrees with the expected size from the corresponding cDNA. To examine the linearity of amplification in the RT-PCR assay, the relationship between amount of RNA, number of PCR cycles, and amount of RT-PCR products was studied. Three step-diluted RNA samples from VSMCs containing 125, 250, and $500 \mathrm{ng}$ of RNA were reverse transcribed and amplified for $20,25,30$, and 35 cycles, and the amounts of PCR products were analyzed by dot blot analysis. To avoid the saturated exposure of x-ray film, we performed multiple short exposures. In a 3-h exposed autoradiogram, the results of RT-PCR from 0 to $500 \mathrm{ng}$ of RNA for 2035 cycles showed good linearity between amount of RNA and intensity of autoradiograms (Fig. 5). From these results, we selected 25 cycles of PCR for the quantification of PDGF Achain mRNA in the tissue. By the same approach as described above, 23 cycles of PCR for G6PD mRNA was used in the present study. The intraassay variation of the assay was $11 \%$ $(n=5)$.

Correlation of PDGF A-chain mRNA in vascular smooth muscle cells with levels of both blood pressure and aortic hypertrophy index. To examine the relationship between blood pressure and PDGF A-chain mRNA levels in VSMCs of SHRs, we investigated the effects of treatment with two different doses of enalapril ( 10 and $25 \mathrm{mg} / \mathrm{kg}$ per d) on gene expression in VSMCs using the RT-PCR assay. Because PDGF A-chain

Figure 2. In situ hybridization histochemistry of rat aortic medial layer. Sections were counterstained with hematoxylin. Rats were 14 wk old $(n$ $=$ three sets of animals). ( $A$ ) aorta from WKY rat hybridized with a ${ }^{35}$ S-labeled PDGF A-chain antisense riboprobe. $(B)$ aorta from SHR hybridized with the same probe. $(C)$ aorta from WKY rat hybridized with ${ }^{35}$ S-labeled PDGF A-chain sense riboprobe. $(D)$ aorta from SHR hybridized with the same probe. Localization was determined by silver grain deposition after autoradiography for $3 \mathrm{~d}$. Antisense PDGF A-chain riboprobe signals were localized in vascular smooth muscle cells of aortic medial layers $(A, B)$, whereas no signals were observed with the ${ }^{35} S$-labeled sense riboprobe $(C, D)$. There were more silver grains per nucleus in the medial layer of SHR aortas than in those of WKY rats. 


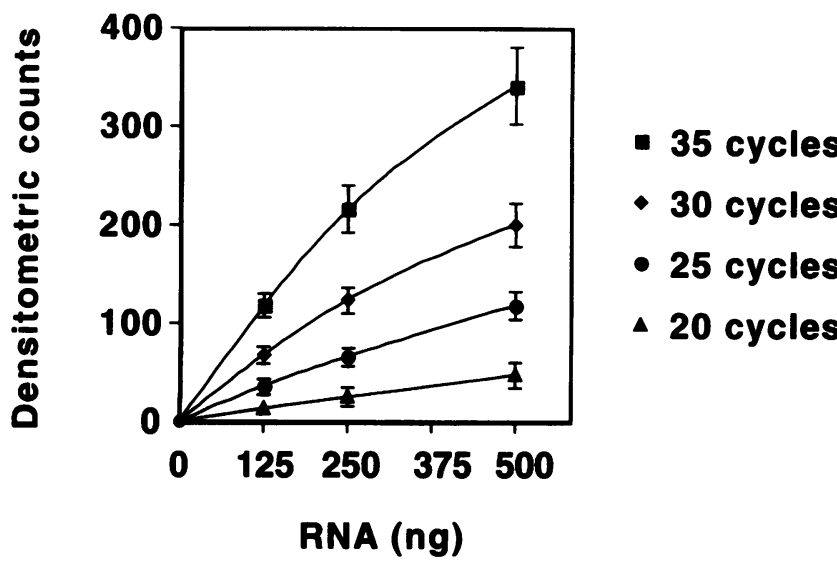

Figure 5. Linearity between number of PCR cycles and amount of RNA samples in RT-PCR assay for PDGF A-chain mRNA. 125, 250, and $500 \mathrm{ng}$ of total RNA from the aortic medial layer were reverse-transcribed and PDGF A-chain mRNA was amplified by PCR with the indicated numbers of cycles. Each sample was analyzed by dot blot hybridization and data was plotted as the mean \pm SE of densitometric counts of the autoradiograms ( $n=3$, respectively).

mRNA and blood pressure levels were not distributed as the standard normal distribution, Spearman's rank correlation test was used for analysis. There was a good correlation between blood pressure and PDGF A-chain mRNA levels in VSMCs of SHRs ( $r s=0.81, P<0.001$; Fig. $6 A$ ), indicating that PDGF A-chain gene expression in VSMCs of SHRs is associated with blood pressure level. This result supports those of the RNase protection assay. There was a good correlation between levels of PDGF A-chain mRNA in VSMCs and hypertrophy index in SHRs ( $r s=0.74, P<0.005$; Fig. $6 B$ ), indicating that PDGF A-chain mRNA levels were associated with the extents of hypertensive vascular hypertrophy of VSMCs in these animals. Treatment with other antihypertensive drugs also showed a good correlation between levels of PDGF A-chain mRNA and blood

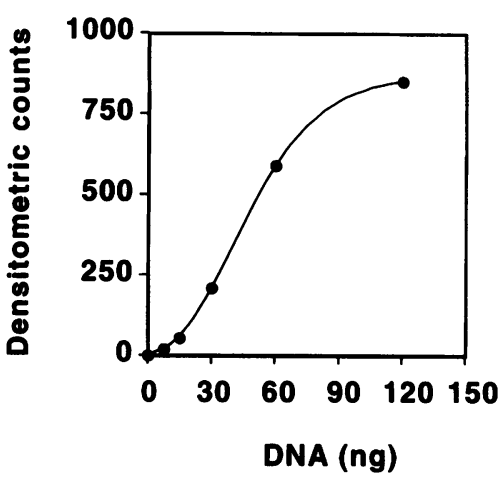

Figure 7. Relationship between amount of extract and intensity of retarded band in gel retardation assay for Spl. Indicated amounts of extracts from aortic medial layers of SHRs were incubated with radiolabeled oligonucleotide probe for Spl and assessed for binding by ge retardation assay. Specificity of retarded bands

was confirmed by presence $(+)$ or absence $(-)$ of unlabeled competitor. A good correlation was observed between amount of samples extracted from aortic medial layers of SHRs and densitometric intensity of bands $(r=0.95, P<0.05)$.

pressure in SHRs (doxazosin, $r s=0.67$; nicardipine, $r s=0.65$; hydralazine, $r s=0.72$ [ $P<0.01 ; n=12$, respectively $]$ ).

Evaluation of gel retardation analysis. To examine the relationship between amount of Sp1 and intensity on autoradiogram, we prepared five step-diluted samples by serial dilutions of cellular extracts of VSMCs of SHRs with extraction buffer and applied these to the assay. The retarded bands which were diminished after coincubation with 25 -fold excess cold competitors were considered to be specific protein-oligonucleotide complex signals. As shown in Fig. 7, there was a good linear relationship between the amount of extracts and densitometric intensity of retarded bands $(r=0.95, P<0.05)$. Evaluating experiments with other transcription factors showed the similar results. We routinely applied each sample containing $50 \mathrm{ng}$ of DNA, equivalent to $\sim 1.6 \times 10^{4}$ nuclei $(26)$, to all assays. Two cycles of freezing and thawing or keeping overnight at $4^{\circ} \mathrm{C}$ did not affect the results. The intraassay variation of the assay was $15 \%(n=5)$.

Levels of transcription factors in vascular smooth muscle

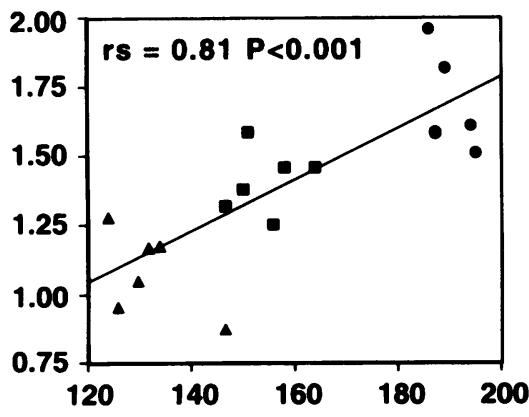

Blood pressure $(\mathbf{m m H g})$

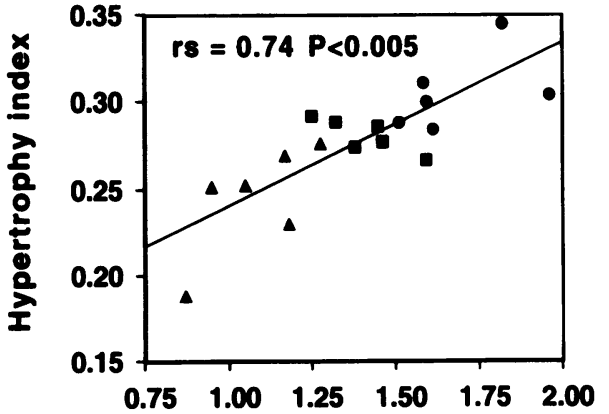

PDGF A-chain gene expression (units)
Figure 6. Correlation between PDGF A-chain gene expression in vascular smooth muscle cells of SHRs with levels of both blood pressure $(A)$ and hypertrophy index $(B) .^{*}$ To lower the blood pressure of SHR, two doses ( 10 $\mathrm{mg} / \mathrm{kg}$ per d, low dose; or $25 \mathrm{mg} / \mathrm{kg}$ per $d$, high dose) of enalapril were administered for $2 \mathrm{wk}$. PDGF A-chain gene expression in aortic medial layer of each SHR was measured by RTPCR assay ( $n=6$ for each). The units indicate the ratio of signal intensities for PDGF A-chain to glucose-6-phosphate dehydrogenase on autoradiograms. Control $(\bullet)$ denotes untreated SHRs; low enalapril ( $\square$ ), SHRs treated with low dose of enalapril; high enalapril $(\Delta)$, SHRs treated with high dose of enalapril. *Determined by Spearman's rank correlation test ( $r s$, Spearman's correlation coefficiency). 


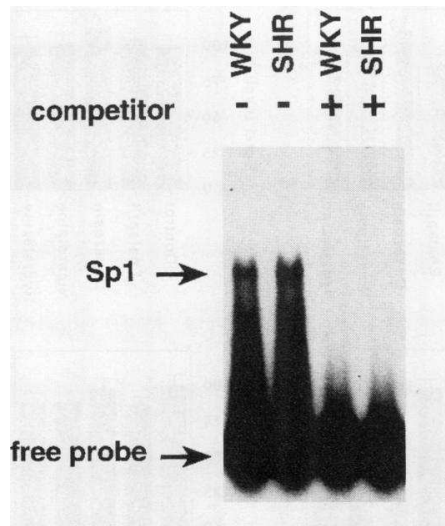

A

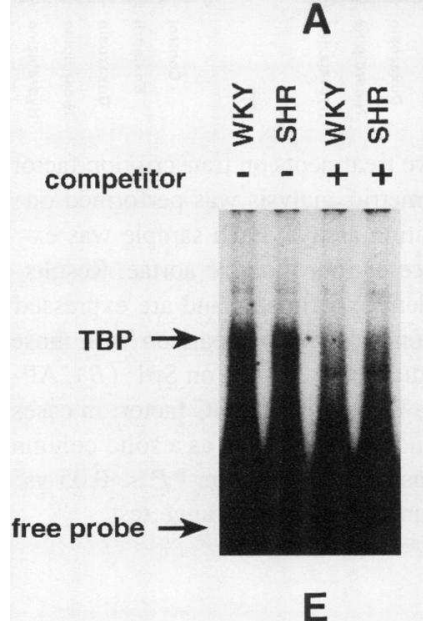

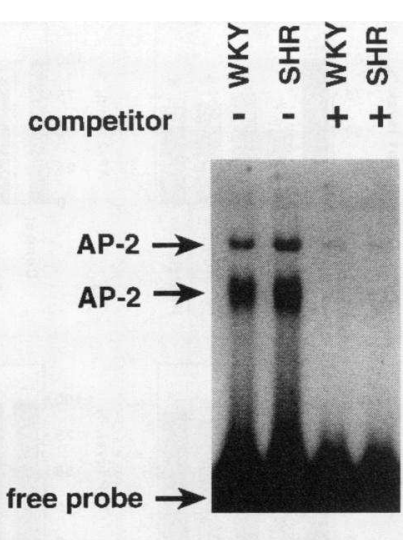

B

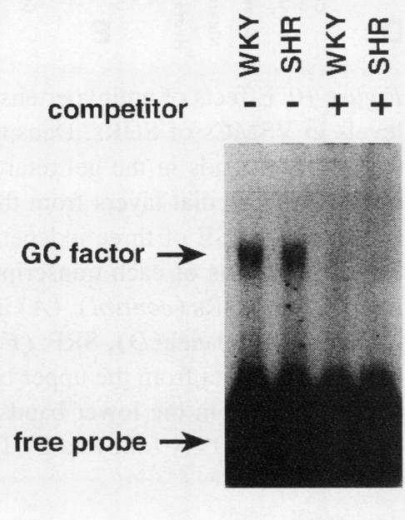

$\mathbf{F}$

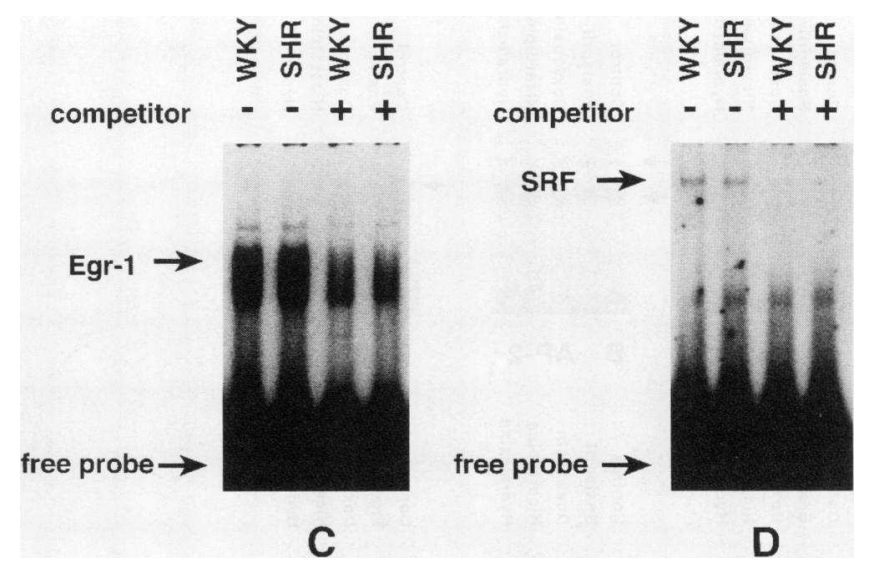

Figure 8. Comparative binding activities to DNA consensus motifs for transcription factors in extracts from VSMCs. Constant amounts of histone-depleted extracts from aortic medial layers $(n=3)$ of WKY rats and SHR were incubated with ${ }^{32} \mathrm{P}$-labeled oligonucleotide probes $(30$ fmol). Specificity of the assay was examined by coincubation with $(+)$ or without $(-)$ 25-fold excess competitor. Protein-oligonucleotide complexes were analyzed by gel electrophoresis. Photographs show gel retardation of probes complexed with Spl $(A), \mathrm{AP}-2(B)$, Egr-1 $(C)$, TBP $(D), \operatorname{SRF}(E)$, and GC factor $(F)$ in aortic smooth muscle cells. Arrows indicate specific complexes of oligonucleotide/transcription factors. Migration of the unbound probe is shown as "free probe." The representative autoradiograms in three independent experiments were shown.

cells. As shown in Fig. 8, all transcription factors except SSRF were identified by the assays, although their signal intensities differed greatly. From the exposure times required to obtain each retarded signal, Sp1, AP-2, and Egr-1 were more abundant in VSMCs than TBP, SRF, or GC factor. The levels of SSRF were very low in VSMCs and difficult to study (data not shown). Results on AP-2 showed the presence of two bands as previously reported, and it has been suggested that the proteins binding to each consensus sequence may be polymerized, complexed, or belonging to a transcription factor family $(18,35)$. Levels of both Sp1 and AP-2 in VSMCs of SHRs were increased to 201 and $183 \%$ of the respective levels in WKY rats. There were almost no differences in the levels of other transcription factors, especially in early growth response gene products Egr1 and SRF (37), between the two rat strains.

Effects of antihypertensive treatments on transcription factors in vascular smooth muscle cells. To determine whether the observed changes in transcription factor levels in VSMCs of SHRs are caused by high blood pressure or genetic background of the strains, we investigated the effects of antihypertensive treatments in vivo. The results showed that after treatment with four pharmacologically different species of antihypertensive drugs for $2 \mathrm{wk}$, Sp1 levels in VSMCs of SHRs decreased approximately to the same level as in that of WKY rats, with a concomitant decrease in PDGF A-chain mRNA levels $(n=3$, $P<0.05$; Fig. 9). The decreases in Sp1 and PDGF A-chain mRNA in VSMCs were also observed after enalapril treatment for 4 wk (data not shown), indicating that these changes were not merely transient cellular responses and that blood pressure levels modulated Sp1 levels in VSMCs of SHRs. In contrast, the amount of AP-2 in VSMCs of SHRs was almost unchanged after antihypertensive treatments (Fig. 10), indicating that increases in AP-2 levels in VSMCs of SHRs are not associated with blood pressure levels but may be caused by the differences in genetic background of the rat strains.

In addition, SRF levels in VSMCs of SHRs were decreased after enalapril treatment for 2 wk ( $n=3, P<0.05$; Fig. 10), and also after enalapril treatment for $4 \mathrm{wk}$ (data not shown), indicating that the change of SRF level caused by enalapril treatment was not a transient cellular response. Other antihypertensive treatments did not significantly alter SRF levels in VSMCs of SHRs, indicating that enalapril has an additional effect by decreasing SRF level in vivo and may play a role in the transcriptional regulation of PDGF A-chain gene in these cells.

\section{Discussion}

The present study demonstrated that PDGF A-chain mRNA levels are increased in hypertrophic VSMCs of SHRs in vivo, and that PDGF A-chain gene expression in these cells is associated with levels of both blood pressure and vascular hypertrophy in SHRs. Gel retardation analysis showed that an increase in Sp1 in VSMCs of SHRs was associated with an increase in PDGF A-chain mRNA induced by high blood pressure in these cells.

We showed that VSMCs from aortic medial layers of adult rats evidently contained PDGF A-chain mRNA by three differ- 


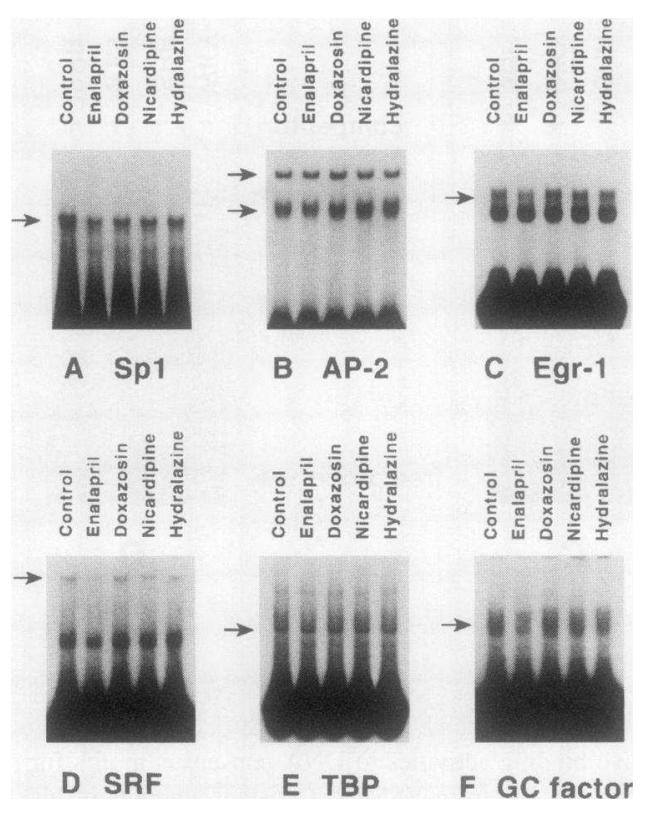

Figure 9. Gel retardation assay for transcription factors in VSMCs from SHRs after antihypertensive treatments. SHRs were treated with the indicated antihypertensive drugs for $2 \mathrm{wk}$ to normalize blood pressure. Untreated SHRs were used as controls. Each sample was extracted from medial layers from three or four thoracic aortas. Constant amounts of extracts were incubated with ${ }^{32} \mathrm{P}$-labeled oligonucleotide probes and protein-DNA complexes were analyzed by gel retardation assays. Photographs show gel retardation of probes complexed with Spl $(A)$, AP$2(B), \operatorname{Egr}-1(C), \operatorname{SRF}(D), \mathrm{TBP}(E)$, and GC-rich factor (GC factor) $(F)$ in VSMCs of aortic medial layers. Arrows indicate the oligonucleotide/transcription factor complexes. The representative autoradiograms in three independent experiments were shown.

ent methods; RNase protection assay, in situ hybridization, and RT-PCR assay. This observation supports the results of previous studies by Barrett et al. and Majesky et al. (3, 14, 15). However, these findings differ significantly from the results of Sarzani et al. $(42,43)$ who reported that PDGF A-chain mRNA levels in rat aortas were too low to study between strains. Although the reason for this difference is unclear, it is possible that $(a)$ the sensitivities of the assays in the former studies including ours were higher than that of Sarzani et al., and $(b)$ the samples used by Sarzani et al. may have been contaminated with adventitial tissue because their samples contained PDGF B-chain mRNA, which is never expressed in VSMCs, but is strongly expressed in aortic adventitial tissue (14).

We demonstrated that PDGF A-chain mRNA level was approximately twofold higher in hypertrophic VSMCs of SHRs than in those from normotensive WKY rats. A previous in vitro study (44) showed that a genetic background of SHRs may affect autocrine production of growth factors in cultured VSMCs, when these cells are stimulated. Therefore, to determine whether the increase in PDGF A-chain gene expression in vivo in VSMCs of SHRs is caused by the genetic background of animals or by high blood pressure, we examined the effect of treatment with four pharmacologically different species of antihypertensive drugs for $2 \mathrm{wk}$. After normalization of blood pressure of SHRs by treatment with each antihypertensive drug, PDGF A-chain mRNA levels in VSMCs of SHRs were decreased to almost the same levels as in WKY rats. RT-PCR
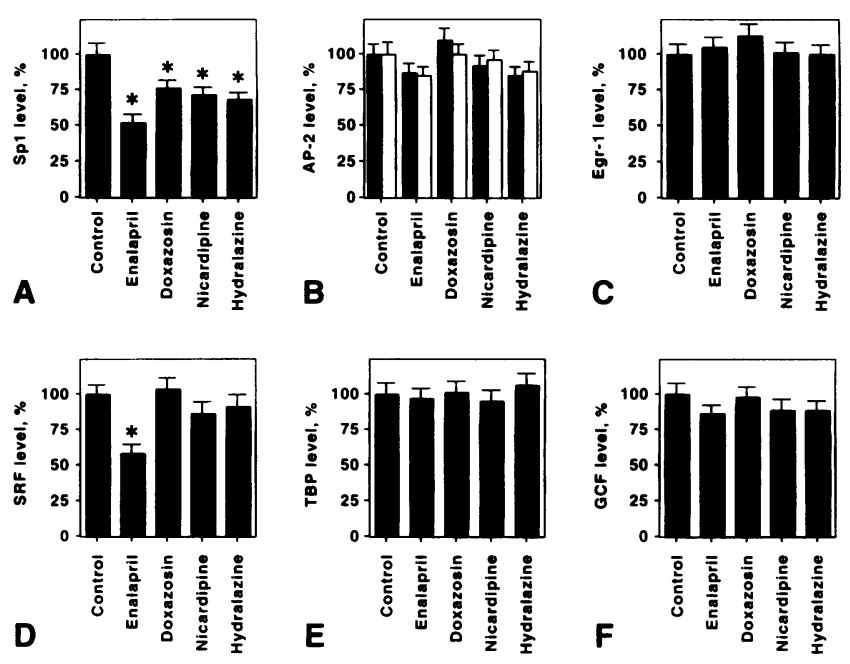

Figure 10. Effects of antihypertensive treatments on transcription factor levels in VSMCs of SHRs. Densitometric analysis was performed on the retarded bands in the gel retardation assays. Each sample was extracted from medial layers from three or four thoracic aortae. Results are the mean $\pm S E$ of three independent experiments and are expressed as relative levels of each transcription factor in comparison with those in untreated SHRs (control). $(A)$ indicates the results on $\mathrm{Spl} ;(B)$, AP2; $(C)$, Egr-1; panel $(D), \mathrm{SRF} ;(E), \mathrm{TBP}$; and $(F), \mathrm{GC}$ factor. In cases on AP-2, the data from the upper bands are expressed as a solid column and the data from the lower bands as an open column. ${ }^{*} P<0.05$ vs control by ANOVA followed by Duncan's multiple range test.

assay showed that blood pressure levels in SHRs were correlated well with PDGF A-chain mRNA levels in the VSMCs. These results suggest that blood pressure regulates PDGF Achain gene expression in VSMCs of SHRs, and that genetic background of the strains is not a primary cause of the observed increases in PDGF A-chain mRNA levels in these cells.

Recent study (45) showed that a low concentration (4.2 pM) of PDGF-AA had mitogenic activity for cultured VSMCs. Itoh et al. (7) and Fukuda et al. (8) reported that transfection of antisense oligonucleotide corresponding to PDGF A-chain mRNA inhibited DNA synthesis in cultured VSMCs. These findings indicate that autocrine PDGF-AA has mitogenic activity for these cells. From these observations, continuous gene expression of PDGF A-chain at twofold elevation in aortic medial layers may enhance the hypertensive vascular hypertrophy of VSMCs in vivo with a moderate increase in PDGF-AA.

A recent report (12) showed that biological activity of PDGF-AA is dependent on the relative number of PDGF $\alpha \alpha$ receptor on the effector cells. Although in vivo VSMCs in normal adult arteries express PDGF A-chain mRNA and PDGF $\alpha$ receptors to some extent $(12,14,15)$, in vivo regulation of the autocrine loop between PDGF-AA and PDGF $\alpha \alpha$ receptor in VSMCs has not been determined (46). Battegay et al. (45) showed that a low concentration of PDGF-AA did not downregulate either PDGF $\alpha$-receptor gene expression or receptor numbers in cultured VSMCs under conditions of stimulated growth. Therefore, it is likely that a moderate increase of PDGF-AA induced by continuous gene expression of PDGF A-chain at twofold elevation in VSMCs of SHRs has mitogenic activity for these cells in vivo, although further study is necessary.

Additionally, it was reported that PDGF-AA may have important nonmitogenic maintenance functions such as chemoat- 
tachment, chemotaxis, glucose metabolism, and vascular tension control in normal arterial tissue (47-49). The increased PDGF-AA in VSMCs of SHRs may modulate these maintenance functions in vivo, although further study is necessary to confirm or refute this hypothesis.

We were interested in the mechanisms by which high blood pressure induces the observed increase in PDGF A-chain gene expression in VSMCs. Since transcription factors play a key role in the control of mRNA synthesis in both proliferating and differentiated cells $(18,19)$, we examined levels of transcription factors related to PDGF A-chain gene in VSMCs of SHRs in vivo. We found that Sp1 and AP-2 were approximately twofold more abundant in hypertrophic VSMCs of SHRs than in those of normotensive WKY rats. As the protein/DNA ratio of in vivo VSMCs from SHRs is only $18 \%$ higher than that of WKY rats (40) and levels of some transcription factors such as Egr-1 in VSMCs were equivalent in the two strains in the present study, it is unlikely that these approximately twofold increases in Spl and AP-2 in VSMCs of SHRs were caused simply by nonspecific increases in protein synthesis. Furthermore, we found that after lowering of blood pressure by antihypertensive treatment, Spl level in VSMCs of SHRs was also decreased, although AP-2 level was not. These results suggest that the observed increase in Sp1 level in VSMCs of SHRs is associated with high blood pressure, but not with genetic background of the rat strains. In contrast, increases in AP-2 in these cells may be caused the genetic background of the rat strains, although we do not know the mechanisms for this effect at present.

After lowering blood pressure by antihypertensive treatments, Sp1 level in VSMCs of SHRs was decreased with a concomitant decrease in PDGF A-chain mRNA level. Lin et al. (50) found that the triple contiguous Sp1 binding sites between -150 and -33 in the promoter region of PDGF A-chain gene have $>80 \%$ of this gene's promoter activity in cultured cells. Courey et al. (51) showed by cotransfection analysis that promoter activity of Sp1 binding sites in the promoter region increased proportionally as $\mathrm{Sp} 1$ concentration was increased. They also showed that Sp1 can act not only as a proximal promoter factor but also as an enhancer binding factor (18) by $\mathrm{Sp} 1-\mathrm{Sp} 1$ interactions. From these observations, the present results suggest that $\mathrm{Sp} 1$ may mediate the transcriptional activation of PDGF A-chain gene induced by high blood pressure in VSMCs. Additionally, because ( $a$ ) Sp1 activates many other genes which may alter PDGF A-chain gene expression and $(b)$ unknown transcription factors which activate the transcription of PDGF A-chain gene may be present in VSMCs, further investigation is needed to determine these possibilities.

Enalapril treatment for 2 and 4 wk decreased SRF (p67 ${ }^{\mathrm{SRF}}$ ) levels in VSMCs of SHRs. SRF is induced by stimulation of serum or protein kinase $C$ activation $(35,37)$, and it regulates transcription of genes such as c-fos and PDGF A-chain by forming ternary complexes as $\mathrm{SRE} / \mathrm{p} 67^{\mathrm{SRF}} / \mathrm{p} 62^{\mathrm{TCF}}$ (52). Angiotensin-converting enzyme inhibitors reduce levels of A II within aortic tissue (53), and A II can stimulate protein kinase $\mathrm{C}$ activity in VSMCs (54). These findings suggest that a decrease in levels of A II in aortic medial layers after enalapril treatment may induce a decrease in SRF levels in VSMCs through downregulation of protein kinase $\mathrm{C}$ activity. Further study using angiotensin receptor antagonists will allow determination of the association of A II with regulation of SRF in VSMCs.
In conclusion, levels of PDGF A-chain mRNA and the related transcription factor $\mathrm{Spl}$ are increased in hypertrophic VSMCs of SHRs compared with those of normotensive rats in vivo. Antihypertensive treatments decrease the levels of PDGF A-chain mRNA and Sp1 in VSMCs of SHRs with concomitant reduction of aortic vascular hypertrophy. These results suggest that an autocrine mechanism inducing PDGF A-chain gene expression by high blood pressure in VSMCs of SHRs may play a role in enhancement of hypertensive vascular hypertrophy, and that an increase in availability of Sp1 in VSMCs induced by high blood pressure may mediate the elevation of PDGF Achain gene expression in these cells.

\section{Acknowledgments}

We wish to thank Miss Yukari Kitano and Miss Michiyo Okumura for their secretarial assistance in the preparation of this manuscript.

\section{References}

1. Heagerty, A. M., C. A. Aalkjær, S. J. Bund, N. Korsgaard, and M. J. Mulvany. 1993. Small artery structure in hypertension. Dual processes of remodeling and growth. Hypertension (Dallas). 21:391-397.

2. Schwartz, S. M., and R. Ross. 1984. Cellular proliferation in atherosclerosis and hypertension. Prog. Cardiovasc. Dis. 26:355-372.

3. Bondjers, G., M. Glukhova, G. K. Hansson, Y. V. Postnov, M. A. Reidy, and S. M. Schwartz. 1991. Hypertension and atherosclerosis. Cause and effects, or two effects with one unknown cause? Circulation. 84:VI-2-VI-16.

4. Hartford, M., I. Wendelhag, G. Berglund, I. Wallentin, S. Ljungman, and J. Wikstrand. 1988. Cardiovascular and renal effects of long-term antihypertensive treatment. JAMA (J. Am. Med. Assoc.). 259:2553-2557.

5. Ross, R., J. Masuda, and W. W. Raines. 1990. Cellular interactions, growth factors, and smooth muscle proliferation in atherogenesis. Ann. NY Acad. Sci. 598:102-112.

6. Ross, R. 1993. The pathogenesis of atherosclerosis: a perspective for the 1990s. Nature (Lond.). 362:801-809.

7. Itoh, H., R. E. Pratt, and V. J. Dzau. 1990. Antisense oligonucleotides complementary to PDGF mRNA attenuate angiotensin II-induced hypertrophy. Hypertension (Dallas). 16:325a. (Abstr.)

8. Fukuda, N., A. Kubo, Y. Izumi, M. Soma, and K. Kanmatsuse. 1994 Suppression of PDGF-A gene by antisense oligodeoxynucleotide inhibits the enhanced growth of vascular smooth muscle cells from SHR. J. Hypertens. 12:S222a. (Abstr.)

9. Raines, E. W., S. K. Dower, and R. Ross. 1989. Interleukin-1 mitogenic activity for fibroblasts and smooth muscle cells is due to PDGF-AA. Science (Wash. DC). 243:393-243.

10. Ikeda, U., M. Ikeda, T. Oohara, A. Oguchi, T. Kamitani, Y. Tsuruya, and S. Kano. 1991. Interleukin 6 stimulates growth of vascular smooth muscle cells in a PDGF-dependent manner. Am. J. Physiol. 260:H1713-H1717.

11. Heldin, C. H. 1992. Structural and functional studies on platelet-derived growth factor. EMBO (Eur. Mol. Biol. Organ.) J. 11:4251-4259.

12. Matui, T. 1991. Two platelet-derived growth factor receptors in vascular smooth muscle cells. Jpn. Circ. J. 55:1027-1035.

13. Sachinidis, A., R. Locher, W. Vetter, D. Tatje, and J. Hoppe. 1990 Different effects of platelet-derived growth factor isoforms on rat vascular smooth muscle cells. J. Biol. Chem. 265:10238-10243.

14. Matsui, T., M. Heidaran, T. Miki, N. Popescu, W. La Rochelle, M. Kraus, J. Pierce, and S. Aaronson. 1989. Isolation of a novel receptor cDNA establishes the existence of two PDGF receptor genes. Science (Wash. DC). 243:800-804.

15. Barrett, T., and E. P. Benditt. 1988. Platelet-derived growth factor gene expression in human atherosclerotic plaques and normal artery wall. Proc. Natl. Acad. Sci. USA. 85:2810-2814.

16. Majesky, M. W., E. P. Benditt, and S. M. Schwartz. 1988. Expression and developmental control of platelet-derived growth factor A-chain and B-chain/ Sis genes in rat aortic smooth muscle cells. Proc. Natl. Acad. Sci. USA. 85:15241528.

17. Owens, G. K., and S. M. Schwartz. 1982. Alterations in vascular smooth muscle mass in the spontaneously hypertensive rat. Role of cellular hypertrophy, hyperploidy, and hyperplasia. Circ. Res. 51:280-289.

18. Mitchell, P. J., and R. Tjian. 1989. Transcriptional regulation in mammalian cells by sequence-specific DNA binding proteins. Science (Wash. DC). 245:371-378.

19. Herschman, H. R. 1989. Extracellular signals, transcriptional responses and cellular specificity. Trends Biochem. Sci. 14:455-458. 
20. Marchuk, D., M. Drumm, A. Saulino, and F. S. Collins. 1990. Construction of T-vectors, a rapid and general system for direct cloning of unmodified PCR products. Nucleic Acids Res. 19:1154.

21. Negoro, N., Y. Kanayama, J. Iwai, N. Umetani, M. Nishimura, Y. Konishi, M. Okamura, T. Inoue, and T. Takeda. 1994. Angiotensin-converting enzyme inhibitor increases angiotensin type $1 \mathrm{~A}$ receptor gene expression in aortic smooth muscle cells of spontaneously hypertensive rats. Biochim. Biophys. Acta. 1226:19-24.

22. Katayose, D., M. Ohe, K. Yamauchi, S. Shibahara, and T. Takishima 1991. Expression of platelet-derived growth factor (PDGF) -A and -B chains in the rat lungs with hypoxic pulmonary hypertension. Am. J. Physiol. 264:L100L106.

23. Ho, Y. S., A. J. Howard, and J. D. Crapo. 1988. Cloning and sequence of a cDNA encoding rat glucose-6-phosphate dehydrogenase. Nucleic Acids Res. $16: 7746$.

24. Uemori, T., Y. Ishino, K. Fujita, K. Asada, and I. Kato. 1993. Cloning of the DNA polymerase gene of Bacillus caldotenax and characterization of the gene products. J. Biochem. 113:401-410.

25. Nakahara, K., H. Nishimura, M. Kuroo, S. Takewaki, M. Iwase, A. Ohubo, Y. Yazaki, and R. Nagai. 1992. Identification of three types of PDGF-A chain gene transcripts in rabbit vascular smooth muscle and their regulated expression during development and by angiotensin II. Biochem. Biophys. Res. Commun. 184:811-818.

26. Sambrook, J., E. F. Fritsch, and T. Maniatis. 1989. Molecular Cloning: A Laboratory Manual: Cold Spring Harbor Laboratory, Cold Spring Harbor, NY.

27. Grierson, D. 1990. Gel electrophoresis of RNA. In Gel Electrophoresis of Nucleic Acids. D. Rickwood and R. D. Hames, editors. Oxford University Press, Oxford, UK. 12-14.

28. Davis, L. G., M. D. Dibner, and J. F. Batty. 1986. Basic Methods in Molecular Biology. Elsevier Science Publishing Co., New York. 355-359.

29. Rorsman, F., and C. Betsholtz. 1992. Characterization of the mouse PDGF A-chain gene. Evolutionary conservation of gene structure, nucleotide sequence and alternative splicing. Growth Factors. 6:303-313.

30. Bonthron, D. T., C. C. Morton, S. H. Orkin, and T. Collins. 1988. Plateletderived growth factor A chain: gene structure, chromosomal location, and basis for alternative mRNA splicing. Proc. Natl. Acad. Sci. USA. 85:1492-1496.

31. Takimoto, Y., Z. Y. Wang, K. Kobler, and T. F. Deuel. 1991. Promoter region of the human platelet-derived growth factor A-chain gene. Proc. Natl. Acad. Sci. USA. 88:1686-1690.

32. Pugh, B. F., and R. Tjian. 1992. Diverse transcriptional functions of the multisubunit eukaryotic TFIID complex. J. Biol. Chem. 267:679-682.

33. Briggs, M. R., J. T. Kadonaga, S. P. Bell, and R. Tjian. 1986. Purification and biochemical characterization of the promoter-specific transcription factor Spl. Science (Wash. DC). 234:47-52.

34. Christy, B., and D. Nathans. 1989. DNA binding site of the growth factorinducible protein Zif268. Proc. Natl. Acad. Sci. USA. 86:8737-8741.

35. Mitchell, P. J., C. Wang, and R. Tjian. 1987. Positive and negative regulation of transcription in vitro: enhancer-binding protein AP-2 is inhibited by SV40 $\mathrm{T}$ antigen. Cell. 50:847-861.

36. Kageyama, R., and I. Pastan. 1989. Molecular cloning and characterization of a human DNA binding factor that represses transcription. Cell. 59:815-825.

37. Norman, C., M. Runswick, R. Pollock, and R. Treisman. 1988. Isolation and properties of cDNA clones encoding SRF, a transcription factor that binds to the c-fos serum response element. Cell. 55:989-1003.
38. Resnick, N., T. Collins, W. Atkinson, D. T. Bonthron, C. F. Dewey, Jr., and M. A. Gimbrone, Jr. 1993. Platelet-derived growth factor B chain promote contains a cis-acting fluid shear-stress-responsive element. Proc. Natl. Acad. Sci. USA. 90:4591-4595.

39. Goodwin, G. H. 1990. The analysis of sequence specific DNA-binding proteins in cell extracts. In Gel Electrophoresis of Nucleic Acids. D. Rickwood and B. D. Hames, editors. Oxford University Press, Oxford, UK. 225-247.

40. Owens, G. K., P. S. Rabinovitch, and S. M. Schwartz. 1981. Smooth muscle cell hypertrophy versus hyperplasia in hypertension. Proc. Natl. Acad. Sci. USA. 78:7759-7763.

41. Siegel, S. 1956. Nonparametric statistics: for the behavioral sciences. McGraw-Hill Inc., New York, 344 pp.

42. Sarzani, R., G. Arnaldi, and A. V. Chobanian. 1991. Hypertension-induced changes of platelet-derived growth factor receptor expression in rat aorta and heart. Hypertension (Dallas). 17:888-895.

43. Sarzani, R., G. Arnaldi, I. Takasaki, P. Brecher, and A. V. Chobanian. 1991. Effects of hypertension and aging on platelet-derived growth factor and platelet-derived growth factor and platelet-derived growth factor receptor expression in rat aorta and heart. Hypertension. 18:93-99.

44. Hahn, A. W. A., T. J. Resink, F. Ferracin, and F. R. Bühler. 1991 Stimulation of autocrine platelet-derived growth factor AA-homodimer and transforming growth factor $\beta$ in vascular smooth muscle cells. Biochem. Biophys. Res. Commun. 178:1451-1458.

45. Battegay, E. J., E. W. Raines, R. A. Seifert, D. F. Bowen-Pope, and R. Ross. TGF- $\beta$ induces bimodal proliferation of connective tissue cells via complex control of an autocrine PDGF loop. Cell. 63:515-524.

46. Hahn, A. W. A., T. J. Resink, E. Mackie, T. Scott-Burden, and F. R. Bühler. 1993. Effects of peptide vasoconstrictors on vessel structure. Am. J. Med. 94:4A-13S-4A-19S

47. Koyama, N., N. Morisaki, Y. Saito, and S. Yoshida. Regulatory effects of platelet-derived growth factor-AA homodimer on migration of vascular smooth muscle cells. J. Biol. Chem. 267:22806-22812.

48. Chan, C. P., D. F. Bowen-Pope, R. Ross, and E. G. Krebs. 1987. Regulation of glycogen synthase activity by growth factors. J. Biol. Chem. 262:276-281.

49. Berk, B. C., R. W. Alexander, T. A. Brock, M. A. Gimbrone, Jr., and R. C Webb. 1986. Vasoconstriction: a new activity for platelet-derived growth factor. Science (Wash. DC). 232:87-90.

50. Lin, X., Z. Wang, L. Gu, and T. F. Deuel. 1992. Functional analysis of the human platelet-derived growth factor A-chain promoter region. J. Biol. Chem 267:25614-25619.

51. Courey, A. J., D. A. Holtzman, S. P. Jackson, and R. Tjian. 1989. Synergistic activation by the glutamin-rich domains of human transcription factor $\mathrm{Spl}$ Cell. 59:827-836.

52. Mrais, R., J. Wynne, and R. Treisman. 1993. The SRF accessory protein Elk-1 contains a growth factor-regulated transcriptional activation domain. Cell. 73:381-393.

53. Morishita, R., J. Higaki, H. Yu, F. Nakamura, N. Tomita, H. Mikami, and T. Ogihara. 1992. Possible role of the vascular renin-angiotensin system in hypertension and vascular hypertrophy. Hypertension (Dallas). 19(Suppl. II) : $62-67$.

54. Taubman, M. B., B. C. Berk, S. Izumo, T. Tsuda, W. Alexander, and B Nadal-Ginard. 1989. Angiotensin II induces c-fos mRNA in aortic smooth muscle. Role of $\mathrm{Ca}^{2+}$ mobilization and protein kinase $\mathrm{C}$ activation. J. Biol. Chem. 264:526-530. 